Nadwa | Jurnal Pendidikan Islam

Vol. 11, Nomor 2 Tahun 2017

\title{
Peningkatan Prestasi Belajar Pendidikan Agama Islam Melalui Penerapan Card Sort Learning
}

\author{
Nur Fadilah \\ SDN 2 Gunungsari Rembang \\ nurfadilah196208@gmail.com
}

\begin{abstract}
Appropriate learning methods should be applied in order to maximize the students' ability during learning activities. The purpose of this study is to determine the improvement of learning achievement of Islamic Religious Education (PAI) through the application of card sort learning method. Action study conducted on PAI learning. The material of this learning is to understand the provision of sholat of fourth graders of Gunungsari State Elementary School 2 Kaliori Sub district Rembang District Lesson Year 2015/2016. The indicator of successful learning in this research is $75 \%$. The results showed that the percentage of learning mastery at the pre cycle stage was $10.7 \%, 67.9 \%$ in the first cycle, and in the second cycle reached $92.9 \%$. The average score of students' test results also increased significantly, ie the pre cycle stage was 58.8, the first cycle was 72.4, and in the second cycle reached 78.9. This means, through the implementation of card sort learning methode can improve student learning achievement on PAI learning material understanding the provision of sholat.
\end{abstract}

Keywords: learning achievement, sholat, card sort

\begin{abstract}
Abstrak
Metode pembelajaran yang tepat harus diterapkan untuk memaksimalkan kemampuan siswa selama kegiatan pembelajaran. Penelitian ini bertujuan untuk mengetahui peningkatan prestasi belajar Pendidikan Agama Islam (PAI) melalui penerapan metode card sort. Studi tindakan (action research) dilakukan pada pembelajaran PAI materi mengenai rukun sholat siswa kelas IV Sekolah Dasar Negeri Gunungsari 2 Kecamatan Kaliori Kabupaten Rembang Tahun Pelajaran 2015/2016. Indikator eHasil penelitian menunjukkan bahwa persentase ketuntasan belajar pada tahap pra siklus sebesar $10,7 \%$, pada siklus I sebesar $67,9 \%$, dan pada siklus II mencapai $92,9 \%$. Nilai rata-rata hasil tes siswa juga mengalami peningkatan yang signifikan, yaitu para tahap pra siklus sebesar 58,8, siklus I sebesar 72,4, dan pada siklus II naik menjadi 78,9. Hal ini berarti, melalui penerapan card sort learning dapat meningkatkan prestasi belajar siswa pada pembelajaran PAI materi mengenal rukun sholat.
\end{abstract}

Kata Kunci : prestasi belajar, sholat, card sort 


\section{Pendahuluan}

Metode pembelajaran adalah cara yang digunakan guru untuk mencapai tujuan pembelajaran. ${ }^{1}$ Metode pembelajaran merupakan bagian dari strategi instruksional, yang didefinisikan sebagai cara untuk menyajikan, menguraikan, memberi contoh, dan memberi latihan kepada peserta didik untuk mencapai tujuan tertentu. Jadi metode pembelajaran adalah cara yang ditempuh oleh seseorang guru untuk mencapai tujuan pembelajaran dengan tahapan-tahapan tertentu. Pemilihan metode belajar yang tepat memungkinkan siswa untuk menguasai ilmu dengan lebih mudah dan lebih cepat sesuai dengan kapasitas tenaga dan pikiran yang dikeluarkan $^{2}$, sehingga dapat menunjang tercapainya tujuan dari kegiatan pembelajaran.

Pemilihan metode pembelajaran harus disesuaikan dengan tujuan pembelajaran yang akan dicapai, pengetahuan awal para peserta didik yang diperoleh melalui pre-tes tertulis maupun tanya jawab diawal pelajaran, serta pokok bahasan yang akan disampaikan dalam kegiatan pembelajaran. Tercapainya tujuan pembelajaran dapat dilihat dari kemampuan minimal yang harus dimiliki oleh setiap peserta didik. Dengan tercapainya tujuan pembelajaran, maka dapat dikatakan guru telah berhasil dalam mengajar.

Bentuk permainan biasanya diterapkan dalam kegiatan pembelajaran untuk meningkatkan keaktifan peserta didik. Kegiatan pembelajaran melalui permainan dapat menciptakan suasana yang kondusif. ${ }^{3}$ Dengan permainan dalam kegiatan pembelajaran, peserta didik akan semakin aktif dan berkembang baik secara kognitif, sosial, emosi dan perkembangan fisiknya. Permainan kartu dengan berbagai variasi dapat digunakan sebagai salah satu media pembelajaran. ${ }^{4}$

Permainan kartu sortir (card sort) yang dikembangkan oleh Mel Siberman dalam bukunya Active Learning merupakan kegiatan kolaboratif yang bisa digunakan untuk mengajarkan

${ }^{1}$ Uno, HB. Model Pembelajaran : Menciptakan Proses Belajar Mengajar Yang Kreatif Dan Efisien. Jakarta: Bumi Aksara, 2008.

${ }^{2}$ Hakim, T. Belajar Secara Efektif. 5th ed. Jakarta: Puspa Swara, 2005.

3 Uno, HB. Model Pembelajaran: Menciptakan Proses Belajar Mengajar Yang Kreatif Dan Efisien. Jakarta: Bumi Aksara, 2008.

${ }^{4}$ Usman, MU. Menjadi Guru Profesional. Bandung: Remaja Rosdakarya, 1998. 
konsep, penggolongan sifat, fakta tentang suatu obyek atau mengulangi informasi. Dalam penerapannya, masing-masing peserta didik diberikan kartu indeks yang berisi materi pelajaran. Kartu indeks dibuat berpasangan berdasarkan definisi, kategori/kelompok. Semakin banyak peserta didik dalam kegiatan pembelajaran maka semakin banyak pula pasangan kartu indeks yang digunakan.

Pendidikan agama merupakan salah satu mata pelajaran yang diharapkan dapat memberikan kontribusi yang signifikan bagi pencapaian tujuan pendidikan nasional, yaitu pembentukan manusia yang bertaqwa dan berbudi pekerti luhur, ${ }^{5}$ sedangkan Pendidikan Agama Islam (PAI) merupakan usaha sadar yang dilakukan oleh pendidik dalam rangka mempersiapkan peserta didik untuk meyakini, memahami dan mengamalkan ajaran agam Islam melalui bimbingan, pengajaran atau pelatihan yang telah ditentukan untuk mencapai tujuan yang harus ditetapkan. ${ }^{6}$

Fiqih merupakan salah satu materi pokok dalam Pendidikan Agama Islam. Salah satu materi fiqih di kelas IV semester 1 adalah Mengenal ketentuan-ketentuan shalat, dengan kompetensi dasar menyebutkan rukun shalat. Rukun Salat adalah setiap perkataan atau juga perbuatan yang akan membentuk hakikat shalat. Jika salah satu dalam rukun ini tidak ada atau tidak dilakukan, maka shalat yang dikerjakan tidak dianggap secara syar' $i$ dan tidak bisa diganti dengan sujud sahwi. ${ }^{7}$ Terdapat 13 rukun sholat yang wajib diketahui, yaitu : niat, takbirotul ikhrom, berdiri tegak, membaca al Fatikhah, rukuk, i'tidal, sujud, duduk di antara dua sujud, duduk akhir, membaca tasyahud akhir, membaca sholawat nabi, mengucapkan salam dan tertib.

Mata Pelajaran PAI dengan materi pembahasan mengenai rukun sholat pada siswa Kelas IV Semester 1 SD Negeri 2 Gunungsari Tahun Pelajaran 2015/2016 belum mencapai target

${ }^{5}$ Hidayat, D R, M Abdurrahman, and Y Nurbayan. "Pendidikan Agama : Urgensi Dan Tantangan." In Ilmu Dan Aplikasi Pendidikan. Grasindo \& PT Imtia, 2007.

${ }^{6}$ Majid, A, and D Andayani. Pendidikan Agama Islam Berbasis Kompetensi. Bandung: Remaja Rosdakarya, 2004. 2003.

${ }^{7}$ Syarifuddin, Amir. Garis-Garis Besar Fiqh. Bogor: Prenada Mrdia, 
yang diinginkan, yaitu siswa memahami dan mampu mempraktekkan rukun sholat dalam amaliah sholat. Sebagian besar siswa belum mencapai target pembelajaran. Hal ini ditengarai karena suasana yang belum kondusif untuk merangsang keaktifan siswa. Metode permainan card sort dipilih sebagai treatment tersebut.

Tujuan dari penelitian ini adalah mengetahui peningkatan prestasi belajar Pendidikan Agama Islam melalui metode card sort pada siswa kelas IV Semester 1 SD Negeri Gunungsari 1 Kecamatan Kaliori Kabupaten Rembang Tahun Pelajaran 2015/2016.

\section{Metode Penelitian}

Penelitian ini dilakukan di SD Negeri 2 Gunungsari Kecamatan Kaliori Kabupaten Rembang selama 3 bulan (September - November 2015). Penelitian dilaksanakan dalam dua siklus (siklus I dan siklus II), yang sebelumnya telah dilaksanakan pembelajaran awal (pra siklus). Subyek penelitian ini adalah siswa Kelas IV SD Negeri 2 Gunungsari, Kecamatan Kaliori Kabupaten Rembang semester 1 Tahun Pelajaran 2015/2016 yang berjumlah 28 siswa, terdiri dari 15 siswa lakilaki dan 13 siswa perempuan.

Penelitian ini diawali dengan observasi awal untuk mendapatkan masalah yang dihadapi oleh siswa dan guru. Aktivitas tersebut diikuti dengan perencanaan, pelaksanaan, pengamatan, dan refleksi. ${ }^{8}$ Kegiatan ini diulang sampai terpenuhinya target yang telah diterapkan dalam indikator kinerja. Dalam penelitian ini keempat tahapan tersebut dilaksanakan dalam 2 siklus yang sebelumnya telah dilaksanakan pembelajaran awal (pra siklus). Setiap tahapan siklus didasarkan atas masukan dari siklus sebelumnya sebagaimana Gambar 1.

\footnotetext{
${ }^{8}$ Arikunto. Penelitian Tindakan Kelas. Jakarta: Bumi Aksara, 2006.
} 


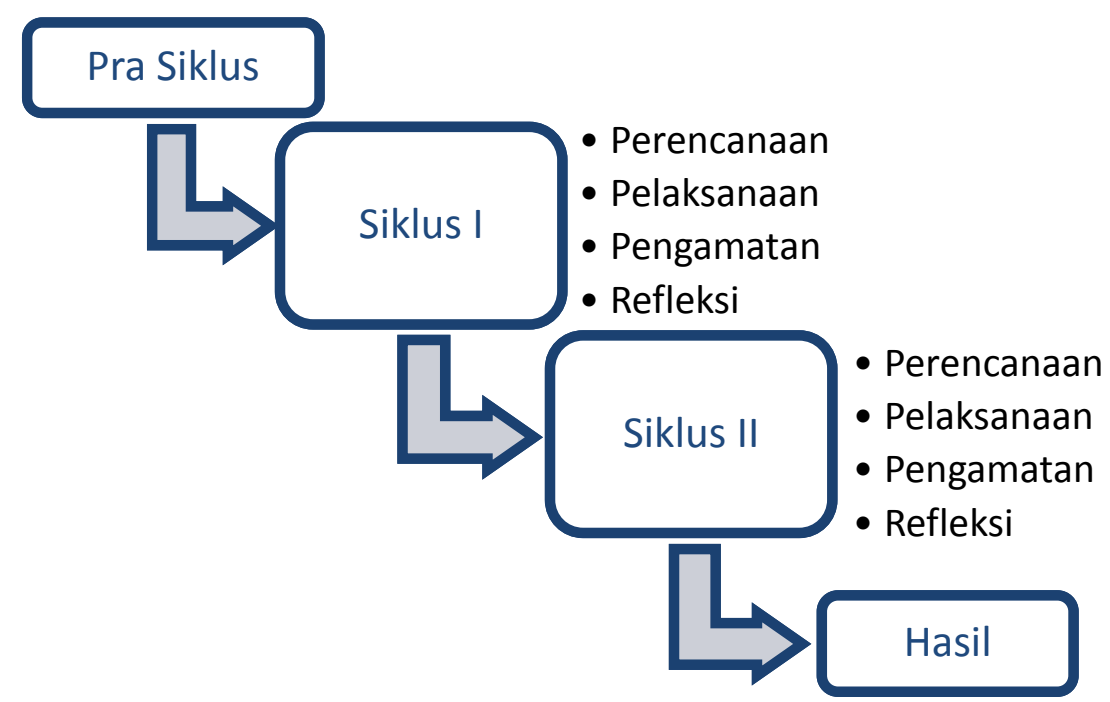

Gambar 1. Rancangan penelitian tindakan kelas melalui :

Dalam penelitian ini, data dikumpulkan secara langsung (1) Tes (evaluasi)

Metode ini digunakan untuk mendapatkan informasi mengenai prestasi belajar peserta didik pada siklus I dan siklus II. Pelaksanaan tes ini dilakukan pada tiap akhir siklus dalam penelitian tindakan kelas. Jenis tes adalah lisan dan tertulis, sedangkan bentuk tes yaitu pilihan ganda dan interview dan observasi. Adapun alat penilaian berupa lembar kerja siswa dan soal tes.

(2) bservasi

Observasi adalah pengamatan dan pencatatan secara sistematis terhadap fenomena atau kejadian yang diselidiki. ${ }^{9}$ Teknik ini digunakan selama proses pembelajaran berlangsung. Lembar observasi diisi oleh teman sejawat untuk mengamati jalan pelaksanaan penelitian tindakan kelas yang dilakukan oleh peneliti. Instrumennya berupa lembar observasi yang telah dirancang bersama oleh guru dan teman sejawat dalam penelitian ini.

\footnotetext{
${ }^{9}$ Hadi, Sutrisno. Metodologi Research. Yogyakarta: Andi Publisher,
} 2002. 


\section{(3) Dokumentasi}

Metode dokumentasi yaitu mencari data mengenai hal-hal yang berupa catatan, transkrip, buku, surat kabar, majalah agenda, dan sebagainya. ${ }^{10}$ Hasil dari dokumentasi akan digunakan sebagai pelengkap dan penguat dari data-data yang didokumentasikan. Metode ini penulis gunakan untuk mendapatkan data rekapitulasi tentang daftar peserta didik, daftar nilai prestasi peserta didik dan aktivitas peserta didik berupa dokumen gambar/foto selama kegiatan pembelajaran.

Validasi data dalam penelitian ini dilakukan dengan proses triangulasi, yaitu hasil observasi dicocokkan dengan hasil tes. Selain itu juga data juga divalidasi dengan hasil observasi yang dilakukan oleh teman sejawat.

Analisis data dilakukan secara deskriptif kuantitatif. Untuk mengetahui peningkatan hasil belajar, maka dibuat nilai rata-rata setiap siklus, dan ketuntasan belajar siswa, kemudian dianalisis untuk mengetahui peningkatan hasil evaluasi disetiap siklus. Indikator kinerja yang digunakan dalam penelitian ini adalah jika jumlah siswa yang menguasai materi mencapai nilai rata-rata kelas (P) 75\% sesuai dengan prestasi yang dicapai.

\section{Hasil Pembelajaran Awal (Pra Siklus)}

Pada kegiatan pembelajaran awal ini peneliti menjelaskan materi menyebutkan rukun sholat pada siswa kelas IV SD Negeri 2 Gunungsari Kecamatan Kaliori. Pada saat pembelajaran awal ini guru melakukan pembelajaran dengan menggunakan metode ceramah dan diselingi dengan tanya jawab mengenai materi mengenal ketentuan-ketentuan sholat.

Berdasarkan Tabel 3, diketahui bahwa hasil belajar siswa masih rendah dan perlu ditingkatkan. Persentase ketuntasan belajar siswa hanya $10,7 \%$ dan masih berada di bawah standar ketuntasan minimal, yaitu $75 \%$.

Tabel 3. Rangkuman hasil belajar siswa pada pembelajaran awal

\begin{tabular}{ccc}
\hline No & Keterangan & Perolehan \\
\hline 1 & Nilai terendah & 50 \\
2 & Nilai tertinggi & 75 \\
\hline
\end{tabular}

${ }^{10}$ Arikunto, Suharsimi. Prosedur Penelitian Suatu Pendekatan Praktek. Jakarta: Rineka Cipta, 2002. 


\begin{tabular}{llc}
\hline 3 & Nilai rata-rata kelas & 58,8 \\
4 & Jumlah peserta didik yang belum tuntas & 25 \\
& belajar & 3 \\
5 & Jumlah peserta didik yang tuntas belajar & $10,7 \%$ \\
6 & Persentase ketuntasan belajar & \\
\hline
\end{tabular}

Berdasarkan hasil pembelajaran awal, diketahui bahwa selama ini guru lebih sering menggunakan metode konvensional yaitu ceramah dan diselingi dengan tanya jawab. Setiap siswa mendapatkan tugas yang sama dengan siswa yang lain. Guru lebih mendominasi selama proses pembelajaran sedangkan siswa lebih banyak mendengarkan dan memperhatikan penjelasan yang disampaikan oleh guru.

Kesempatan siswa untuk mengemukakan pendapat masih sedikit. Kegiatan belajar mengajar terkesan monoton dan kurang memberikan motivasi bagi siswa untuk belajar. Peserta didik hanya menulis dan mendengar penjelasan yang disampaikan oleh guru, sehingga mereka hanya termotivasi auntuk mengingat dan menghafal materi. Hasil observasi terhadap siswa maupun guru selama proses pembelajaran awal disajikan dalam Tabel 4.

Tabel 1. Hasil observasi pada pembelajaran awal

\begin{tabular}{clc}
\hline No & \multicolumn{1}{c}{ Aspek yang diamati } & Skor \\
\hline A & Siswa & \\
\hline 1 & Motivasi siswa dalam proses pembelajaran & 1 \\
2 & Keaktifan siswa bertanya & 2 \\
3 & Kemampuan siswa dalam menjawab pertanyaan & 2 \\
4 & Keaktifan siswa dalam berdiskusi & 1 \\
5 & Kerjasama siswa dalam menyelesaikan tugas yang & 1 \\
6 & diberikan & 2 \\
7 & Kerhatian siswa dalam mendengarkan informasi & 2 \\
\hline Jumlah Skor & 11 \\
\hline Persentase & $39,3 \%$ \\
& & Kurang \\
\hline B & Guru & 3 \\
1 & Persiapan guru dalam mengajar & 3 \\
2 & Penguasaan materi pembelajaran & \\
\hline
\end{tabular}




\begin{tabular}{llc}
\hline 3 & Penyampaian materi urut sesuai tingkat perkembangan & 3 \\
4 & siswa & 1 \\
5 & Penggunaan alat peraga & 3 \\
6 & Pengerian motivasi terhadap siswa & 3 \\
7 & Kemampuan guru dalam melaksanakan penilaian & 3 \\
\hline Jumlah Skor & 19 \\
\hline Persentase & $67,9 \%$ \\
\hline
\end{tabular}

Keterangan:

- skor terdiri atas 1 (kurang), 2 (cukup), 3 (baik), dan 4 (sangat baik)

- Terdapat 7 aspek yang dinilai, sehingga total skor adalah 28 .

- Kriteria penilaian : $<43,8 \%$ (kurang); $>43,8-62,5 \%$ (cukup); $>62,5-81,3 \%$ (baik); dan $>81,3 \%$ (sangat baik).

Dari hasil observasi di atas dapat diketahui bahwa persentase keaktifan siswa dalam mengikuti pembelajaran adalah 39,3\% dengan kriteria kurang. Persentase tersebut masih berada di bawah indikator keberhasilan tindakan yaitu 75\%. Meskipun keaktifan guru selama proses pembelajaran tergolong baik namun tidak diikuti oleh keaktifan peserta didik. Hal ini dikarenakan kurangnya penggunaan alat peraga. Penyampaian materi secara konvensional dengan metode ceramah dan tanya jawab kurang dapat merangsang keaktifan siswa selama proses pembelajaran. Selain itu, metode ceramah juga kurang dapat memberikan motivasi kepada siswa untuk belajar, berdiskusi, maupun bekerjasama dalam mengerjakan tugas yang diberikan.

Berdasarkan hasil tes dan observasi pada kegiatan pembelajaran awal dapat diketahui beberapa permasalahan pada pembelajaran Pendidikan Agama Islam di kelas IV SD Negeri 2 Gunungsari Kecamatan Kaliori Kabupaten Rembang Tahun ajaran 2015/2016 dengan materi mengenal rukun sholat, yaitu : Hasil belajar siswa masih rendah yaitu 58,8 dan masih berada jauh dibawah nilai ketuntasan minimal (75) dan tingkat keaktifan siswa dalam kegiatan pembelajaran masih kurang, terutama karena kurangnya motivasi dalam belajar dan kurangnya keaktifan dalam berdiskusi maupun kerjasama dalam menyelesaikan tugas yang diberikan oleh guru, serta rendahnya 
hasil belajar siswa ini diasumsikan disebabkan oleh kurangnya penggunaan alat peraga dalam proses pembelajaran.

Observasi awal ini dijadikan bahan pertimbangan untuk pemberian tindakan dalam pembelajaran PAI agar dapat mencapai ketuntasan belajar minimal. Untuk mengatasi berbagai masalah dan kelemahan pembelajaran PAI dengan materi rukun sholat tersebut maka dilakukan tindakan berupa penerapan metode card sort dalam pembelajaran.

\section{Hasil Pelaksanaan Tindakan Kelas}

\section{Siklus I:}

Perencanaan : Berdasarkan permasalahan yang telah diidentifikasi pada saat pembelajaran awal maka telah direncanakan metode pembelajaran pada siklus I yaitu metode card sort. Perencanaan pengajaran pada siklus I ini dituangkan dalam bentuk RPP. Materi yang dibahas pada siklus I adalah Fiqih Ibadah dengan standar kompetensi mengenal ketentuan-ketentuan sholat, dengan kompetensi dasar menyebutkan rukun sholat. Selain RPP, peneliti juga mempersiapkan instrumen lainnya seperti kartu sortir yang berisi materi-materi Fiqih Ibadah, lembar observasi untuk peserta didik dan guru, serta lembar soal.

Pelaksanaan : tindakan pada siklus I dilaksanakan sebanyak satu kali pertemuan dengan alokasi waktu 2 x 35 menit. Materi pembelajaran adalah rukun sholat yang dilaksanakan sesuai dengan jadwal dan prosedur yang telah direncanakan dalam RPP. Dalam menjelaskan materi ini, guru juga memperlihatkan kartu-kartu yang berisi tentang rukun sholat dan bacaannya. Selama proses pembelajaran guru juga mengajak siswa untuk berperan aktif dalam pembelajaran. Guru meminta siswa untuk membaca tulisan yang ada di kartu yang ditunjukkan secara bersama-sama. Guru juga memberikan kesempatan kepada siswa untuk mengajukan pertanyaan jika masih materi yang kurang dipahami. Setelah itu, guru mengacak kartu-kartu yang berisi materi rukun sholat tersebut sehingga tercampur menjadi satu. Guru membagikan kartu-kartu tersebut kepada setiap peserta didik. Setiap peserta didik minimal mendapatkan satu kartu, namun ada beberapa peserta didik yang mendapatkan dua kartu. 
Kartu terbagi menjadi dua bagian yaitu kartu induk dan kartu rinciannya. Kartu induk berisi tentang sub materi yaitu rukun sholat, sedangkan kartu rincian berisi tentang bacaan dan gerakan dalam sholat. Kemudian guru memerintahkan setiap siswa untuk menyusun rukun sholat secara urut dan menempelkannya di papan. Setelah siswa selesai menyusun kartu-kartu tersebut, guru melakukan koreksi bersama terhadap pekerjaan siswa tersebut. Setelah semuanya selesai, guru memberikan apresiasi dengan memberikan nilai terhadap hasil kerja siswa.

Pada akhir siklus I guru melakukan tes untuk mengukur hasil belajar siswa. Hasil belajar siswa pada siklus I tersebut dapat dilihat pada tabel 5 .

Tabel 2. Rangkuman hasil belajar siswa pada siklus I

\begin{tabular}{clc}
\hline No & Keterangan & Perolehan \\
\hline 1 & Nilai terendah & 60 \\
2 & Nilai tertinggi & 80 \\
3 & Nilai rata-rata kelas & 73,4 \\
4 & Jumlah peserta didik yang belum tuntas belajar & 10 \\
5 & Jumlah peserta didik yang tuntas belajar & 19 \\
6 & Persentase ketuntasan belajar & $67,9 \%$ \\
\hline
\end{tabular}

Berdasarkan Tabel 5, diketahui bahwa siswa yang mencapai ketuntasan belajar atau memperoleh nilai sama atau lebih dari 75 sebanyak 19 orang. Sisanya sebanyak 10 orang masih belum mencapai nilai ketuntasan minimal. Rata-rata hasil belajar siswa secara klasikal adalah 73,4. Deskripsi data tersebut memperlihatkan bahwa sudah ada peningkatan nilai hasil belajar siswa. Hal ini dapat dilihat nilai rata-rata kelas pada pra siklus 58,8 naik menjadi 73,4 pada siklus I, sedangkan ketuntasan klasikal $10,7 \%$ pada pembelajaran awal naik menjadi $67,9 \%$ pada siklus I.

Walaupun rata-rata kelas sudah mengalami peningkatan tetapi indikator keberhasilan ketuntasan klasikal sebesar 75\% masih belum tercapai sehingga perlu diadakan perbaikan pada siklus II.

Observasi : Selama pembelajaran berlangsung aktivitas guru maupun siswa diamati oleh rekan sejawat. Adapun hasil observasi mengenai aktivitas siswa dan guru pada siklus I ini dapat dilihat pada tabel berikut. 
Tabel 3. Hasil observasi pada pembelajaran siklus I

\begin{tabular}{clc}
\hline No & \multicolumn{1}{c}{ Aspek yang diamati } & Skor \\
\hline A & Siswa & \\
\hline 1 & Motivasi siswa dalam proses pembelajaran & 3 \\
2 & Keaktifan siswa bertanya & 3 \\
3 & Kemampuan siswa dalam menjawab pertanyaan & 3 \\
4 & Keaktifan siswa dalam berdiskusi & 2 \\
5 & $\begin{array}{l}\text { Kerjasama siswa dalam menyelesaikan tugas yang } \\
\text { diberikan }\end{array}$ & 3 \\
6 & Perhatian siswa dalam mendengarkan informasi & 3 \\
7 & $\begin{array}{l}\text { Kemampuan siswa mendemonstrasikan secara } \\
\text { individu }\end{array}$ & 3 \\
\hline Jumlah Skor & 20 \\
\hline Persentase & $71,4 \%$ \\
\hline
\end{tabular}

\section{B Guru}

1 Persiapan guru dalam mengajar 4

2 Penguasaan materi pembelajaran 4

3 Penyampaian materi urut sesuai tingkat 3

4 Penggunaan alat peraga 3

5 Pemberian motivasi terhadap siswa 3

6 Penggunaan alokasi waktu yang sesuai 4

7 Kemampuan guru dalam melaksanakan penilaian 4

\begin{tabular}{lc}
\hline Jumlah Skor & 25 \\
\hline Persentase & $89,3 \%$ \\
& Sangat \\
& Baik \\
\hline
\end{tabular}

Keterangan:

- $\quad$ skor terdiri atas 1 (kurang), 2 (cukup), 3 (baik), dan 4 (sangat baik)

- Terdapat 7 aspek yang dinilai, sehingga total skor adalah 28.

- Kriteria penilaian : $<43,8 \%$ (kurang); $>43,8-62,5 \%$ (cukup); $>62,5$ $-81,3 \%$ (baik); dan $>81,3 \%$ (sangat baik).

Berdasarkan data Tabel 6, dapat diketahui bahwa persentase aktivitas belajar siswa pada siklus I mencapai $71,4 \%$ dan termasuk dalam ketegori baik. Namun demikian, dengan persentase aktivitas tersebut belum mencapai 
ketuntasan minimal dalam kegiatan pembelajaran, yaitu $75 \%$. Aspek aktivitas belajar peserta didik yang masih perlu untuk ditingkatkan dalam pembelajaran selanjutnya adalah keaktifan dalam berdiskusi.

Selain aktivitas belajar peserta didik, keberhasilan pembelajaran juga dipengaruhi oleh aktivitas pembelajaran yang dilakukan oleh guru sebagai pendidik. Pada Tabel 6 di atas, persentase aktivitas pembelajaran yang dilakukan oleh guru mencapai $89,3 \%$ dan termasuk dalam kategori sangat baik. Hal ini menunjukkan bahwa guru telah melakukan pengelolaan pembelajaran dengan sangat baik. Pengelolaan tersebut masih tetap perlu ditingkatkan sehingga dapat meningkatkan aktivitas belajar siswa pada tahap pembelajaran selanjutnya. Dengan demikian ketuntasan belajar minimal dapat tercapai.

Refleksi : Berdasarkan hasil belajar siswa serta hasil observasi terhadap aktivitas siswa dan guru pada pembelajaran Siklus I, dapat dirumuskan beberapa perubahan sebagai berikut :pertama : Terjadi peningkatan nilai hasil belajar siswa, yaitu nilai rata-rata pada pra siklus sebesar 58,8 naik menjadi 73,4 pada siklus I. Ketuntasan pembelajaran pada pra siklus sebesar $10,7 \%$ naik menjadi $67,9 \%$ pada siklus I. Namun demikian belum mencapai ketuntasan pembelajaran minimal (75\%). Ke-dua : aktivitas siswa pada siklus I sudah termasuk dalam kategori baik $(71,4 \%)$, namun belum mencerminkan aktivitas belajar yang tinggi, ini dapat dilihat dari persentase aktivitas siswa yang belum mencapai 75\% (ketuntasan minimal). Beberapa aspek yang penting untuk diperbaiki dalam pembelajaran selanjutnya adalah keaktifan siswa dalam berdiskusi. $\mathrm{Ke}$ tiga : Pengelolaan pengajaran yang dilakukan oleh guru sudah berada pada tingkat sangat baik $(89,3 \%)$, namun demikian belum cukup untuk memberikan motivasi kepada siswa untuk mencapai ketuntasan pembelajaran minimal. Melihat hasil refleksi ini maka perlu adanya perbaikanperbaikan dalam pembelajaran pada siklus berikutnya untuk meningkatkan hasil pembelajaran maupun aktivitas belajar siswa. 


\section{Siklus II}

Perencanaan : Pada siklus II ini peneliti merencanakan pembelajaran dengan metode yang sama pada siklus I hanya saja mengalami beberapa perbaikan berdasarkan hasil refleksi siklus I. Perencanaan tindakan pada siklus I tertuang dalam RPP. Materi yang dibahas pada siklus I adalah Fiqih Ibadah dengan standar kompetensi: mengenal rukun sholat. Instrumen lainnya yang dipersiapkan adalah kartu sortir yang berisi bacaan dan gerakan dalam rukun sholat, lembar observasi untuk peserta didik, lembar observasi untuk guru, dan lembar soal.

Pelaksanaan : Pelaksanaan tindakan pada siklus II dilaksanakan sebanyak satu kali pertemuan dengan alokasi waktu 2 x 35 menit. Pokok bahasan yang diajarkan pada siklus II ini adalah rukun shalat. Pelaksanaan pembelajarannya mengacu pada RPP (Rencana Pelaksanaan Pembelajaran) yang telah dipersiapkan. Prinsip pelaksanaan pembelajaran pada siklus II ini hampir sama dengan siklus I, tetapi guru lebih menekankan pada pemberian motivasi agar persentase aktivitas siswa lebih tinggi dari pada siklus I. Pada akhir siklus II juga dilakukan tes akhir untuk mengukur hasil belajar siswa. Hasil tes akhir pada siklus II selengkapnya dapat dilihat pada tabel berikut.

Tabel 4. Rangkuman hasil belajar siswa pada siklus II

\begin{tabular}{clc}
\hline No & \multicolumn{1}{c}{ Keterangan } & Perolehan \\
\hline 1 & Nilai terendah & 70 \\
2 & Nilai tertinggi & 85 \\
3 & Nilai rata-rata kelas & 78,9 \\
4 & Jumlah peserta didik yang belum tuntas & 2 \\
& belajar & 26 \\
5 & Jumlah peserta didik yang tuntas belajar & $92,9 \%$ \\
6 & Persentase ketuntasan belajar & \\
\hline
\end{tabular}

Berdasarkan Tabel 7, diketahui bahwa hampir semua siswa (26 orang) telah mencapai ketuntasan pembelajaran minimal dengan hasil tes sama atau melebihi 75 , sisanya sebanyak 2 anak belum mencapai nilai ketuntasan pembelajaran minimal. Persentase ketuntasan belajar pada siklus II sebesar $92,9 \%$ dan telah mencapai ketuntasan pembelajaran minimal $(75 \%)$. 
Jika dibandingkan dengan hasil pembelajaran siklus I, telah terjadi peningkatan pada hasil pembelajaran siklus II. Hal ini dapat dilihat nilai rata-rata kelas pada siklus I sebesar 73,4 naik menjadi 78,9 pada siklus II dan ketuntasan klasikal $67,9 \%$ pada siklus I naik menjadi $92,9 \%$ pada siklus II.

Ketuntasan klasikal yang diperoleh dari hasil tes pembelajaran siklus II ini telah memenuhi persyaratan yang digunakan sebagai salah satu indikator keberhasilan pembelajaran, karena nilai rata-rata ketuntasan klasikal telah melebihi indikator keberhasilan yaitu 75\%. Dengan kata lain, hasil belajar yang dicapai pada siklus II sudah tuntas.

Observasi : Selama pembelajaran berlangsung aktivitas guru maupun siswa tetap diamati. Adapun hasil observasi mengenai aktivitas siswa dan guru pada siklus II ini dapat dilihat pada tabel berikut.

Tabel 5. Hasil observasi pada pembelajaran siklus II

\begin{tabular}{|c|c|c|}
\hline No & Aspek yang diamati & Skor \\
\hline $\mathbf{A}$ & Siswa & \\
\hline 1 & Motivasi siswa dalam proses pembelajaran & 4 \\
\hline 2 & Keaktifan siswa bertanya & 4 \\
\hline 3 & Kemampuan siswa dalam menjawab pertanyaan & 4 \\
\hline 4 & Keaktifan siswa dalam berdiskusi & 3 \\
\hline 5 & $\begin{array}{l}\text { Kerjasama siswa dalam menyelesaikan tugas yang } \\
\text { diberikan }\end{array}$ & 3 \\
\hline 6 & Perhatian siswa dalam mendengarkan informasi & 4 \\
\hline 7 & $\begin{array}{l}\text { Kemampuan siswa mendemonstrasikan secara } \\
\text { individu }\end{array}$ & 4 \\
\hline \multicolumn{2}{|c|}{ Jumlah Skor } & 26 \\
\hline \multicolumn{2}{|c|}{ Persentase } & $\begin{array}{c}92,9 \% \\
\text { Sangat } \\
\text { baik }\end{array}$ \\
\hline B & Guru & \\
\hline 1 & Persiapan guru dalam mengajar & 4 \\
\hline 2 & Penguasaan materi pembelajaran & 4 \\
\hline 3 & $\begin{array}{l}\text { Penyampaian materi urut sesuai tingkat } \\
\text { perkembangan siswa }\end{array}$ & 4 \\
\hline
\end{tabular}




\begin{tabular}{clc}
\hline 4 & Penggunaan alat peraga & 3 \\
5 & Pemberian motivasi terhadap siswa & 4 \\
6 & Penggunaan alokasi waktu yang sesuai & 4 \\
7 & Kemampuan guru dalam melaksanakan penilaian & 4 \\
\hline Jumlah Skor & 27 \\
\hline Persentase & $96,4 \%$ \\
& Sangat \\
& Baik \\
\hline
\end{tabular}

Keterangan:

- $\quad$ skor terdiri atas 1 (kurang), 2 (cukup), 3 (baik), dan 4 (sangat baik)

- Terdapat 7 aspek yang dinilai, sehingga total skor adalah 28 .

- Kriteria penilaian : $<43,8 \%$ (kurang); $>43,8-62,5 \%$ (cukup); $>62,5$ $-81,3 \%$ (baik); dan $>81,3 \%$ (sangat baik).

Tabel di atas memperlihatkan bahwa aktivitas belajar siswa mengalami peningkatan dari siklus I yang hanya $71,4 \%$ menjadi $92,9 \%$ pada siklus II. Pada siklus II ini aktivitas belajar siswa berada dalam kategori sangat baik dan sudah melampaui persentase ketuntasan pembelajaran minimal, yaitu $75 \%$. Ini berarti aktivitas belajar siswa sudah mencapai indikator keberhasilan tindakan. Selain itu, pengelolaan pembelajaran yang dilakukan oleh guru juga sangat baik dengan persentase sebesar 96,4\%. Hal ini menunjukkan guru sudah sangat baik dalam melakukan pengelolaan pembelajaran.

Refleksi : Berdasarkan hasil belajar siswa serta hasil observasi terhadap aktivitas siswa dan guru pada pembelajaran Siklus II, dapat dirumuskan beberapa hal sebagai berikut : Pertama : Hasil belajar siswa pada siklus II sudah lebih baik dibandingkan dengan siklus I. Hal ini dapat dilihat nilai rata-rata kelas pada siklus I sebesar 73,4 naik menjadi 78,9 pada siklus II dan ketuntasan klasikal 67,9\% pada siklus I naik menjadi 92,9\% pada siklus II. Hal ini berarti ketuntasan klasikal telah melebihi indikator keberhasilan yaitu $75 \%$. Jadi hasil belajar siswa pada siklus II sudah tuntas. Ke-dua : Aktivitas siswa mengalami peningkatan dari siklus I yang hanya 71,4\% menjadi $92,9 \%$ pada siklus II. Dengan demikian ketuntasan minimal pembelajaran telah terpenuhi. Ke-tiga : Pengelolaan 
pembelajaran yang dilakukan guru pada siklus II tergolong sangat baik dengan persentase yang lebih besar daripada siklus I.

\section{Pembahasan}

Hasil penelitian di atas menunjukkan bahwa baik hasil belajar maupun aktifitas siswa mengalami peningkatan yang cukup signifikan di setiap siklusnya. Hasil belajar peserta didik diukur melalui tes evaluasi yang dilakukan pada tiap akhir siklus. Indikator keberhasilan tindakan kelas tersebut adalah apabila standar ketuntasan hasil belajar peserta didik mencapai 75\%.

Pada siklus I pembelajaran difokuskan pada implementasi metode card sort. Metode ini baru pertama kali diimplementasikan di Sd Negeri 2 Gunungsari Kecamatan Kaliori Kabupaten Rembang. Jadi secara teknis, baik guru maupun peserta didik belum sepenuhnya memahami penerapan metode tersebut dalam pembelajaran PAI. Sebelum penelitian ini dimulai, guru dan teman sejawat telah melakukan diskusi mengenai penerapan metode card sort dalam pembelajaran PAI. Meskipun begitu penerapan metode ini pada siklus I masih mengalami beberapa kendala, di antaranya kemampuan siswa dalam berdiskusi. Guru kelihatan masih kewalahan pengelolaan pembelajaran, terutama mengorganisir siswa dalam menemukan kartu induk dan kartu rinciannya. Namun kendala ini dengan cepat diatasi oleh guru dengan cara mengorganisir siswa yang membawa kartu induk, sehingga siswa yang membawa kartu rincian dapat dengan mudah menemukan kartu induknya.

Hasil penelitian pada siklus I ini menunjukkan peningkatan dibandingkan pada tahap pra siklus (pembelajaran awal). Pada tahap pra siklus nilai rata-rata hasil belajar siswa adalah 58,8 dan ketuntasan pembelajaran mencapai $10,7 \%$, sedangkan pada siklus I nilai rata-rata peserta didik adalah 73,4 dan ketuntasan pembelajaran sebesar $67,9 \%$. Hal ini menunjukkan adanya peningkatan ketuntasan pembelajaran yang cukup signifikan. Persentase aktifitas belajar siswa pada tahap pra siklus adalah 39,3\% sedangkan pada siklus I naik menjadi 71,4\%. Meskipun ada peningkatan, namun hasil dari siklus I belum memenuhi standar ketuntasan minimal yang telah ditetapkan dalam penelitian ini, sehingga perlu dilakukan tindakan pada pembelajaran selanjutnya yaitu siklus II. 
Pada siklus II, guru dan rekan sejawat memfokuskan tindakan pada peningkatan aktivitas siswa dalam kegiatan pembelajaran. Peserta didik dituntut untuk lebih aktif dalam pembelajaran dengan cara tiap anggota peserta didik diminta untuk menjelaskan hasil sortiran mereka, tidak hanya perwakilan seperti pada siklus I. Dengan cara seperti ini, peserta didik jadi lebih aktif dalam pembelajaran. Disamping itu, mereka juga lebih memahami materi yang sedang diajarkan oleh guru sekaligus dapat meningkatkan kemampuan mereka dalam berdiskusi.

Hasil belajar siswa mengalami peningkatan. Pada siklus I nilai rata-rata hasil belajar siswa adalah 73,4 dengan ketuntasan pembelajaran mencapai $67,9 \%$, sedangkan pada siklus II nilai rata-rata peserta didik adalah 78,9 dengan ketuntasan pembelajaran mencapai $92,9 \%$. Hal ini menunjukkan adanya peningkatan yang cukup signifikan. Untuk persentase aktifitas belajar siswa pada siklus I adalah 71,4\% sedangkan pada siklus II naik menjadi $92,9 \%$. Ada peningkatan aktivitas siswa yang cukup signifikan. Hal ini menunjukkan bahwa hasil peserta didik sudah memenuhi target yang ditetapkan peneliti.

Peningkatan hasil belajar siswa di setiap siklus dapat dilihat pada Tabel 9 dan Gambar 2.

Tabel 6. Peningkatan hasil belajar siswa setiap tahap pembelajaran

\begin{tabular}{clcc} 
No & Tahap Pembelajaran & $\begin{array}{c}\text { Nilai } \\
\text { Rata-Rata }\end{array}$ & $\begin{array}{c}\text { Persentase Ketuntasan } \\
\text { Pembelajaran (\%) }\end{array}$ \\
\hline 1 & Pembelajaran awal & 58,8 & 10,7 \\
\hline 2 & Siklus I & 73,4 & 67,9 \\
\hline 3 & Siklus II & 78,9 & 92,9 \\
\hline
\end{tabular}




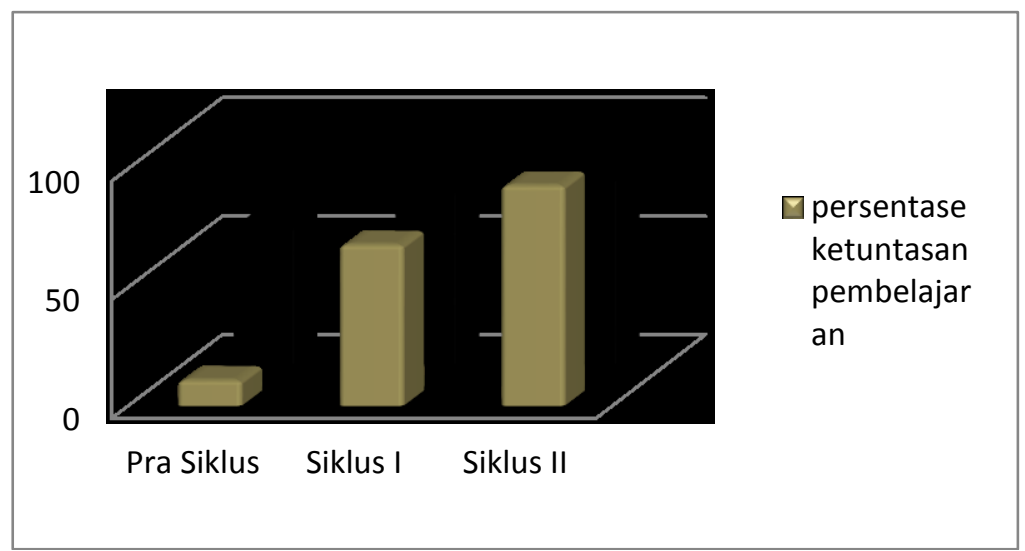

Gambar 2. Peningkatan hasil belajar siswa

Peningkatan aktivitas belajar siswa di setiap siklus dapat dilihat pada Tabel 10 dan Gambar 3.

Tabel 7. Peningkatan aktivitas siswa setiap tahap pembelajaran

\begin{tabular}{clcc}
\hline No & Tahap Pembelajaran & $\begin{array}{c}\text { Skor } \\
\text { Rata-Rata }\end{array}$ & $\begin{array}{c}\text { Persentase Aktivitas } \\
\text { Belajar (\%) }\end{array}$ \\
\hline 1 & Pembelajaran awal & 2 & 39,3 \\
2 & Siklus I & 3 & 71,4 \\
3 & Siklus II & 4 & 92,9 \\
\hline
\end{tabular}

Keterangan : skor 1 (kurang, 2 (cukup), 3 (baik), dan 4 (sangat baik)

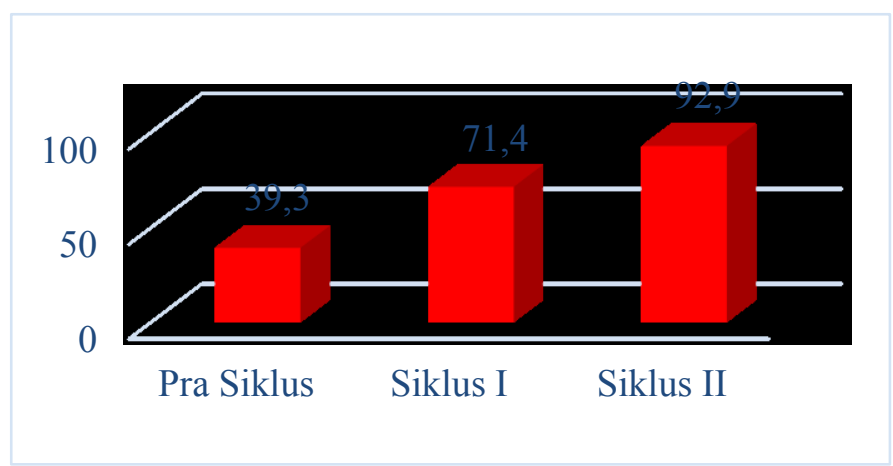

Gambar 3. Peningkatan hasil belajar siswa

Keberhasilan penelitian tindakan kelas ini tidak terlepas dari peran guru yang secara kontinyu memperbaiki kemampuannya dalam menerapkan metode card sort. Metode card sort ini memiliki beberapa keunggulan antara lain : Pertama 
: Pembelajaran terasa menyenangkan, siswa dapat bermain sambil belajar. Secara psikologis siswa pada tingkat pendidikan dasar sangat menyukai permainan. Mereka lebih menyukai permainan dari pada aktivitas kognitif yang membutuhkan pemahaman tinggi. Oleh karena itu, guru harus dapat memanfaatkan potensi ini untuk meningkatkan keberhasilan pembelajaran. Metode Card Sort menggunakan media kartu sebagai pengantar materi pelajaran. Media kartu ini termasuk dalam kategori permainan. Dalam implementasinya peserta harus mencari kartu induk dan rinciannya di antara teman-teman sekelasnya. Aktivitas ini tidak hanya mangasah aspek kognitif tetapi juga melatih ketangkasan peserta didik, sehingga pembelajaran terasa menyenangkan. Disamping itu tampilan kartu yang ditampilkan dengan warna warna yang mencolok dapat memancing ketertarikan peserta didik terhadap metode ini. Ke dua : Meningkatkan aktivitas siswa, dalam impelementasinya, siswa diharuskan untuk berinteraksi dan berkomunikasi dengan teman sekelasnya. Sehingga aktifitas ini menuntut peserta didik untuk lebih aktif dalam pembelajaran. Ke-tiga : Materi yang disampaikan lebih gampang diingat, pesan-pesan pendek yang ada pada setiap kartu sortir tersebut dapat diingat oleh peserta dengan lebih mudah. Karena yang ditampilkan didalam kartu bukan deskripsi materi yang panjang, melainkan sub-sub materi yang simple dan mudah diingat.

\section{Simpulan}

Penerapan metode Card Sort pada pembelajaran PAI mempermudah guru dalam mencapai target belajar yang diinginkan dan dapat mengoptimalkan suasana belajar siswa untuk menuntaskan hasil belajar peserta didik. Disamping itu Penerapan metode Card Sort juga dapat merangsang dan memunculkan keaktifan siswa. 


\section{Daftar Pustaka}

Arikunto. 2006. Penelitian Tindakan Kelas. Jakarta: Bumi Aksara.

Arikunto, S. 2006. Dasar-Dasar Evaluasi Pendidikan. Jakarta: Bumi Aksara.

Arikunto, Suharsimi. 2002. Prosedur Penelitian Suatu Pendekatan Praktek. Jakarta: Rineka Cipta.

Hadi, Sutrisno. 2002. Metodologi Research. Yogyakarta: Andi Publisher.

Hakim, T. 2005. Belajar Secara Efektif. 5thed. Jakarta: Puspa Swara.

Hidayat, D R, M Abdurrahman, and Y Nurbayan. 2007. "Pendidikan Agama : Urgensi Dan Tantangan." In Ilmu Dan Aplikasi Pendidikan. Grasindo \& PT Imtia.

Majid, A, and D Andayani. 2004. Pendidikan Agama Islam Berbasis Kompetensi. Bandung: Remaja Rosdakarya.

Syarifuddin, Amir. 2003. Garis-Garis Besar Fiqh. Bogor: Prenada Mrdia.

Uno, HB. 2008. Model Pembelajaran: Menciptakan Proses Belajar Mengajar Yang Kreatif Dan Efisien. Jakarta: Bumi Aksara.

Usman, MU. 1998. Menjadi Guru Profesional. Bandung: Remaja Rosdakarya 